\title{
(息)
}

Citation:

McKie, D and Willis, P (2014) Advancing tendencies? PR leadership, general leadership, and leadership pedagogy. Public Relations Review. ISSN 0363-8111 DOI: https://doi.org/10.1016/j.pubrev.2014.02.020

Link to Leeds Beckett Repository record:

https://eprints.leedsbeckett.ac.uk/id/eprint/1221/

Document Version:

Article (Accepted Version)

The aim of the Leeds Beckett Repository is to provide open access to our research, as required by funder policies and permitted by publishers and copyright law.

The Leeds Beckett repository holds a wide range of publications, each of which has been checked for copyright and the relevant embargo period has been applied by the Research Services team.

We operate on a standard take-down policy. If you are the author or publisher of an output and you would like it removed from the repository, please contact us and we will investigate on a case-by-case basis.

Each thesis in the repository has been cleared where necessary by the author for third party copyright. If you would like a thesis to be removed from the repository or believe there is an issue with copyright, please contact us on openaccess@leedsbeckett.ac.uk and we will investigate on a case-by-case basis. 


\section{Advancing tendencies? PR leadership, general leadership, and leadership pedagogy}

Professor David McKie

Management Communication Department, University of Waikato, Hamilton 3240, New Zealand

*Corresponding author. Tel.: + 647838 4197; e-mail: dmckie@ waikato.ac.nz

Paul Willis

Centre for Public Relations Studies, Leeds Business School, Leeds Metropolitan University, 25, Queen Square, Leeds, LS2 8AF, United Kingdom

Tel: +44 011381 23578. E-mail address: p.a.willis@leedsmet.ac.uk

\section{Abstract}

What are the best ways to advance PR leadership? In exploring answers, we consider the last two decades of PR literature and identify two main tendencies. We link those two with general leadership literature and practices, as well as with literature on leadership pedagogy. We conclude that, rather than recent moves to look within the field, without selfreflection, to existing PR perspectives and figures for solutions, looking outwards has greater potential to transform not only the PR leadership literature, and PR practice, but also to create less hierarchical, and more democratic and "leaderful," PR workplaces. 


\title{
Advancing tendencies? PR leadership, general leadership, and leadership pedagogy
}

\begin{abstract}
What are the best ways to advance PR leadership? In exploring answers, we consider the last two decades of PR literature and identify two main tendencies. We link those two with general leadership literature and practices, as well as with literature on leadership pedagogy. We conclude that, rather than recent moves to look within the field, without selfreflection, to existing PR perspectives and figures for solutions, looking outwards has greater potential to transform not only the PR leadership literature, and PR practice, but also to create less hierarchical, and more democratic and "leaderful," PR workplaces.
\end{abstract}

\section{Introduction: a tale of two tendencies}

Contemporary leaders face the challenge of operating in fast-changing, unpredictable, and unsettled environments where chaotic turbulence, "is the new normality" [italics in original] (Kotler \& Caslione, 2009, p. xii). PR leaders confront the same conditions but have had less academic attention and there is little agreement on how to answer the question: what are the best ways to advance PR leadership in this context? In examining this question in the light of the last two decades of literature on leadership and PR we explore two main tendencies in the field that have implications for research, practice and pedagogy.

The first and most striking feature is that much of the writing on leadership has tended to emerge from scholarship where the subject of PR leadership is rarely central and even relatively peripheral to other topics. We suggest, however, that examples of this peripheral focused work have much to add to the PR leadership body of work. The second tendency is a predisposition towards insularity in existing PR research that does seek to specifically address the issue of leadership in public relations. Drawing out the strengths and weaknesses of both tendencies we favor interdisciplinary engagement over isolation and going beyond functional competence to benchmark leadership success in the PR field.

\section{Advancing PR leadership (1): Peripheral pathways}

Providing valuable insights into PR leadership, and sometimes leadership in general, peripheral focused work is primarily concerned with areas other than PR leadership per se. Without mentioning a single leadership text, Heath and Waymer's (2009) analysis of Frederick Douglass' "Fourth of July Address," offers a detailed historical case study of how an activist leader used PR effectively in relation to the PR leadership legacy of the founders of the US Declaration of Independence. Demetrious (2013) considers how more contemporary activists defined as "special interest groups, lobby groups or NGOs (nongovernment organisations)" assume "moral leadership" on many global issues and create a "strong fear" (p. 25) among public relations institutions and practitioners. Another cluster of examples features such women-centered studies as Aldoory's (1998) article on "The Language of Leadership for Female Public Relations Professionals," Aldoory and Toth's (2004) consideration of gender in transformational and transactional leadership styles, and Grunig, Toth, and Hon's (2001) Women in Public Relations: How Gender Influences Practice. All three have gender and PR, rather than leadership or PR leadership as their main focus. This is reflected in the relatively small engagement with general leadership and limited range of leadership references. Even without making it a primary focus, each of those 
studies advances specific aspects of leadership. Most particularly, their concern is the ongoing issue, not just in PR but across private and public sector organizations alike (see Kellerman \& Rhode, 2007), of the underrepresentation of women in leadership.

The relatively peripheral positioning of other PR leadership research also appears in books not concentrating on gender issues. Gilpin and Murphy's influential (2008) book, for example, does address the role of leaders - particularly in turbulent conditions - but is relatively marginal to their central concern with crisis management. Nevertheless, their adaptation of complexity theory to deal with uncertainty has clear applicability to the leadership challenges posed by the climate of ongoing change and uncertainty. They also usefully link leadership and PR issues directly though such references as Budd's (1993) CEO Credibility: The Management of Reputation.

In a later work, Gilpin and Murphy (2010) recommend that PR extend complexity theory beyond crisis communication to such areas as "media relations, stakeholder identification, issues management, and organizational reputation" (p. 71). Gilpin and Murphy (2010) note how this aligns with other PR scholars' calls (Bentale, 2007; Ihlen \& van Ruler, 2007) for "more careful reflection on the linkages between public relations research and larger bodies of theory to expand the scope of the discipline and situate it more effectively within an interdisciplinary, pluralistic framework" (p. 71). Gilpin and Murphy $(2008,2010)$ practice what they preach by mobilizing a broad range of readings with wide linkages across different disciplines. This breadth enables them to avoid insularity and to attract a range of readers beyond PR practitioners and leaders while still being of importance to those audiences.

Their work also connects with a growing stream of research concerned that leadership - in both theory and practice - does not exclude others by being considered the sole province of CEOs and people in positions of hierarchical power. Specifically, they follow expert guidance recommending against "assigning all responsibility to a single crisis management leader because effective teams usually produce more positive outcomes" (Gilpin \& Murphy, 2008, p. 133). This orientation to democratic shared leadership is captured in Raelin's (2003) book title Creating Leaderful Organizations: How to Bring Out Leadership in Everyone. It has grown in prominence not only to enable organizations to adapt quickly to change but also "because the new rules of relationships created by the advent of social technologies require that you develop new skills and behaviors that accentuate your own individual leadership style" (Li, 2010, p. 189) and because old ideas of attaching leadership to hierarchical positions can act as obstacles to more democratic and flexible workplaces designed to respond to turbulent environments.

Along similar lines, Holtzhausen's (2012) brief consideration of transformational leadership - often invoked as a response to radical change - is almost incidental to her book's concentration on postmodern PR and the role of the practitioner as activist. Yet she too draws from general leadership thinking and brings plural bodies of thought that range from postmodern ethics in sociology to activist leaders in South African history as role models. She sets them in a broad social and international, as well as a US organizational, context. Berger and Reber's (2006) book on gaining influence and resistance has only a few pages focused directly on leadership but deals with the central leadership issues of influence, 
power, and politics. Although, with only one leadership reading, they reference general leadership even less than the others. Indeed, none of these writers draw much more from the rich and vast leadership literature. Other PR books that do consult that body of work also tend to restrict their citations to a few readings relevant to their particular focus. McKie and Munshi's (2007) short account of learning from leadership for PR, for example, has 15 general leadership references but they form one small part of a larger project reconfiguring PR for contemporary challenges.

\section{Advancing PR leadership (2): Centering new research}

In recent authoritative publications, the lack of direct focus on PR leadership, with one exception, is implicitly criticized. In his Encyclopedia of Public Relations (Heath, 2013) entry on "Leadership and Public Relations," Berger (2013) does not stop at correctly stating that although "general leadership research has proliferated in the past century, few of these studies have focused on leadership in public relations" (pp. 508-509), but situates that lack of a central focus on PR leadership as a problem. Indeed, he offers an emerging solution in "new research" which "is beginning to clarify leadership issues in the field, highlight key dimensions of leadership practice, and improve our understanding of how public relations leaders might be better prepared for a dynamic and uncertain future" (p. 509). For Berger (2013), the "new research" advanced "more rapidly with the formation in 2005 of the Plank Center for Leadership in Public Relations at the University of Alabama" (p. 509), because, from its inception, the Center "seeks to recognize and help develop outstanding [PR] leaders and role models in practice and education and to build a research-based foundation about [PR] leadership" (p. 509). In addition, the Center "has supported more than 20 studies, which have highlighted the influence of role models on employees and how they learn about leadership ... regarding what constitutes excellence in public relations leadership" (Berger, 2013, p. 509).

Berger (2013) goes on to repeat his point that until "recently, few public relations studies have directly explored leadership in the field" (Berger, 2013, p. 509), but does acknowledge that the roles and characteristics of leaders are implicit in several theoretical perspectives. While the creation of a role for implicit insight from peripherally-oriented research is welcome, there is, unfortunately, only one example: "the IABC Excellence Study led by James E. and Larissa A. Grunig [that] outlined some general values and characteristics associated with excellent public relations practice" (p. 509). We classify this example as unfortunate for three reasons: the datedness of the source and its incompatibility with leadership, as distinct from management, thinking; the lack of recognition of how contested and divisive the Excellence Project has become; and the fact of its presence coming at the cost of even one up-to-date leadership reading makes PR inward-looking and insular. Each of these has a bearing on our key question: what are the best ways to advance PR leadership in this context?

The first reason is because such an old study for the early 1990s is less likely to offer guidance to the "dynamic and uncertain future" (Berger, 2013, p. 509) of the second decade of the 21st century and also because it is so management focused. Secondly, it is now seven years since what McKie and Munshi (2007) called "a critical mass of dissonant voices" (p. 47) rejected the "Grunigian paradigm" (Moloney, 2006, p. x) and others have added to the chorus of dissent subsequently (Brown, 2010; Holtzhausen, 2013). Fears for a restoration of 
the former dominance of two-way symmetry that many have found unhelpful, are fuelled further by Berger's (2013) reference list. He assigns one of only four recommended further readings to Grunig's (1992) collection. For a review of PR leadership over 20 years later, to position that book as a quarter of the readings is a cause for concern. The concern is compounded because Berger's solitary general leadership source is a dated edition of Northouse's (2007) Leadership: Theory and Practice textbook. His citation list does not even reference it as the fourth edition. This matters because it then excludes updates subsequently available from at least Northouse's (2010) fifth edition, if not the sixth edition (Northouse, 2013). Berger rightly notes a lack of PR leadership in general leadership but the absence of even one up-to-date general leadership reading in the PR leadership encyclopedia entry is also a serious absence. Its lack of currency and utility surfaces in the leadership advice that follows from Berger's (2013) application of Excellence values and practices:

Applied to leadership, these characteristics suggest that public relations leaders should (1) be involved in strategic decision-making processes in organizations, (2) possess a managerial worldview and vision for communication, (3) possess professional knowledge and experience, and (4) use and model two-way communication. (p. 509)

Examining these in turn reveals the cost of including old general PR at the expense of recent leadership: number (1) only makes sense in terms of the move for entry to the dominant coalition and it is hard to see any PR leader, or any leader, who would not want to be so involved so it is hardly helpful guidance; number (2) simply ignores the key division between leaders and managers that is part of any leadership 101 course since Kotter's (1990) A Force for Change: How Leadership Differs from Management. It is outmoded to advise PR leaders to seek a managerial worldview rather than a leadership worldview; number (3) does not seem to make any additional sense for leaders since professional knowledge and experience would be entry level for a practitioner let alone a PR leader; and number (4) continues the push to have "two-way communication" as the answer to all problems when no other field has adopted it and when there are many more sophisticated dialogue and communication framing writings more relevant to both PR leaders and leaders in general (Fairhurst, 2011).

Additional concerns arise from the restriction of further reading to just one book chapter (Berger \& Meng, 2010) and one article (Meng, Berger, Gower, \& Heyman (2012), when both pieces include Berger as co-author and both emerged from the Plank Center's new research that the entry champions to the exclusion, except the Excellence project, of all else. While peripheral approaches to PR leadership may have lacked direct focus they were less insular and consulted general leadership sources.

\section{Advancing PR leadership (3): Looking outwards and not-so-splendid isolation}

This move toward looking inwards to PR for PR leadership contrasts sharply with the orientation and openings of two articles published near the start of our 20-year period. In the first, Holladay and Coombs' (1993) abstract begins by stating that "The concept of charismatic leadership has emerged as a central concern in leadership research" (p. 405), goes on to clarify the study "the impact of delivery on perceptions of leader charisma" ( $p$. $405)$, and concludes that the "concept of communicator style is offered as a way to interpret 
the findings" (p. 405). In other words the article is partly premised on two ideas: the first that what is central in leadership is worthy of study in its own right; and the second that communication theory and research can be used to augment leadership in terms of charisma. In the following year, the same authors take a similar stance in relation to vision with an article that opens with the sentence "During the past several years, both popular and academic writings on leadership have emphasized the importance of vision (e.g., Bass, 1990b; Bennis \& Nanus, 1985; Bryman, 1992; Conger, 1991, 1992; Tichy \& Devanna, 1986)" [italics in original] (Coombs \& Holladay, 1994). As scholarship, these two approaches offer logical ways forward; namely, review what is current in the leadership literature and relate it to PR. In addition is has an audacity of hope from PR scholars in suggesting that in both topics, communication can advance understanding and practice.

It is the lack of an outward focus and currency that hinder Berger's (2013) new research tendency. Consider the slow lack of engagement with such contemporary developments as globalization although it has featured strongly in the leadership literature, especially through Project GLOBE Project (House et al., 2004; Javidan et al., 2010), which studied leadership and organizations across sixty-two cultures. These have resulted in the Plank Center discussions being geographically and conceptually constrained. The insularity is visible in its most prominent and authoritative output to date: the benchmarking chapter "Public Relations Practitioners and the Leadership Challenge" (Berger \& Meng, 2010). Both scholars link with the Plank Center (Berger is on its advisory board and Meng did her doctorate at the University of Alabama) and the chapter appears, appropriately, as a state of the art summary in the benchmark book of the end of that decade, Heath's (2010) SAGE Handbook of Public Relations.

Their chapter begins with a general and rather unstructured overview of the landscape of leadership research, without much of a focus and rehashes Northouse's (2007) rather dated list of themes from the 1920 s to the 1990 s so that Transformational and Authentic Leadership feature but not the post-2000 concerns with Adaptive Leadership (Lewin \& Regine, 2007), Distributed Leadership (Gronn, 2002; Bolden, 2011), Relational Leadership (Uhl-Bien, 2006), or the "Leaderful Organization" (Raelin, 2003). After about a one-page summary, Berger and Meng (2010) move to more current, detailed, and structured coverage of PR leadership research. Despite the general literature being massive, their review of it is both thin - only 12 out of the 44 references are on general leadership - and dated - only three (Scarnati, 2002; Sosik et al., 2004; Northouse, 2007) of the 12 are later than 1999. In contrast, 29 of the listed reference entries concern PR leadership, or PR itself, and 24 are later than 1999 with 11 from 2009 alone.

As well as being much more comprehensive and up-to-date than the leadership review, Berger and Meng's (2010) review of PR leadership also presents a meta-analysis of 16 recent PR leadership studies conducted by the Plank Center. While they note that the data generated is drawn largely from the US, they don't note that the other research covered in their overview is also focused mainly on the activities of US academics and practitioners. This is as true in their general leadership authors (Bass, 1997; Northouse, 2007; Yukl, 1989) as their PR leadership authors (Aldoory \& Toth, 2004; Berger \& Reber, 2006; Lamb \& McKee, 2004). This North American bias spills over into a rather separatist call to arms to other scholars in the field as they conclude that few studies in PR have explored the leadership 
field directly and suggest a "national dialogue" (Berger \& Meng, 2010, p. 421) rather than an international, or open, dialogue. Since then, the Plank Center has begun to address global issues but only by introducing PR scholarship on PR leadership from elsewhere (http://www.awpagesociety.com/2013/01/new-global-study/).

From our non-US perspective, the focus becomes more about congratulatory navel gazing partially underwritten by assumptions that what the best of the present and past do is the best model for the future. This manifests in the collecting of interviews under titles such as "Profiles of Success: Stories of Emerging Leaders"

(http://issuu.com/theplankcenter/docs/profiles_book_5e75a20dad75c3) and other accounts such as the 2007 Living Legends Panel, which offers videos of the presentation at the 2008 PRSSA Conference with "John (Jack) W. Felton, Steven J. Harris, Thomas W. Hoog and Dr. Debra A. Miller" (http://plankcenter.ua.edu/?s=living+legends). Unfortunately, for PR's public image, we tend to be legends in our field rather than in society. Until PR earns positive public recognition then neither the field nor its leaders have too much cause for celebration. The prototype of the method is again two-way symmetric theory, which attempted a similar, go-it-alone creation of a theory unique to PR in a fashion that neglected relevant contemporary advances in other fields.

\section{External benchmarking (1): Back to interdisciplinarity}

The isolationism goes against not just Gilpin and Murphy (2010) and other PR authors but the grain of the times in what is an age of interdisciplinarity accompanied by attempts to insert academic fields into public sphere discourse. In discussing historiographies, for example, Megill (2011) foregrounds how reflections on the multiplicity of perspectives in that intellectual field work not just internally, but also outside in the wider court of public opinion by promoting:

a critical attitude toward present-day pundits, think-tankers, and overconfident social scientists who offer prescriptions for future action based on a very narrow conception of how human beings exist in the world, a form of prescriptivism that too often attempts to apply its prescriptions to the world in general. (pp. 680-681).

That would be particularly useful in a PR field with a low public reputation. For it to happen, PR needs to cultivate sustained interactions with other fields as history has done in relation to such diverse fields as cosmology, econometrics, environmental studies, fiction, political science, and psychology (see Christian, 2011) and have thought leaders entering wider public discussions.

Instead Berger and Meng's narrow national gaze is paralleled by a blinkered conceptual gaze. Their attempt to construct a PR leadership model is further restricted by its conceptualisation of leadership as individualized, a trait that is prevalent across the field. For example, their call for PR leaders to employ a transformational style of leadership is informed by the work of other PR scholars who have favoured such an approach (Aldorry, 1998; Aldoory \& Toth, 2004; Choi \& Choi, 2008; Jin, 2009; Werder \& Holtzhausen, 2009). Yet Berger and Meng's own sources point to flaws in this. Yukl (1999) argues that transformational leadership is fatally flawed due to its heroic framing of the leader and Northhouse (2013) notes that "by focussing primarily on the leader, researchers have failed 
to give attention to shared leadership or reciprocal influence" (p. 203). This way of looking at leadership is characterised by what Jermier (1998) frames as hierarchical influence and top down control. His warning on the dangers of this approach is based on the argument that processes in organisations unfold in unpredictable ways so leadership cannot be about simply adhering to a conventional, and essentially linear, command and control mindset. Northouse (2013) further questions the efficacy of the transformational perspective citing observations that research has yet to establish that the leaders identified as such are able to transform individuals and organisations. While it is recognised that transformational leadership is associated with positive outcomes such as organisational effectiveness, "studies have not yet clearly established a causal link between transformational leaders and changes in followers of organisations" (Northouse, 2013, p. 203).

Berger and Meng's theoretical offering on leadership is a good illustration of the traditional, rational-analytic and prescriptive perspective which pervades the PR literature. This is evidenced in Berger and Meng's (2010) discussion of the communication and rhetorical capabilities they claim leaders should possess. At the highest level of proficiency in this category they discuss the importance of particular communication skills. Berger and Meng's (2010) focus on skills fails to do justice to the essential qualitative difference in the proficiency leaders need. In particular they ignore contextual intelligence and how individual practitioners have to continually adapt and reconfigure their technical knowledge to cope with an uncertain environment.

\section{External benchmarking (2): Contrasting challenges and contrasting literatures}

The insularity also leads to the most startling omission in their whole chapter, especially one that has "the Leadership Challenge" in its title. Although their major post-2000 leadership source, Northouse (2007) has long had a best-selling leadership textbook, the world's top leadership training book is almost certainly Kouzes and Posner's (2012) The Leadership Challenge: How to Make Extraordinary Things Happen in Organizations. It could be argued that a 2012 publication date made it impossible for Berger and Meng (2010) to include this in time for their reference list. However, this 2012 fifth edition is the 25th anniversary edition of a classic leadership book and four earlier editions would have been available for consultation. The exact echo of "Leadership Challenge" in Berger and Meng's (2010) own title suggests some influence. After the familiar confirmation of the dearth of PR leadershipspecific research, Berger and Meng (2010) reorient the purpose of Kouzes and Posner's subtitle challenge - "to make extraordinary things happen in organizations" - to the smaller and more specific challenge of "directly exploring leadership in the field" [authors' italics] (p. 421) and "to begin what we hope will be a national dialogue about leadership in public relations, or what we refer to as the "leadership challenge"' (p. 421).

The limited PR leadership challenge is valid. Nevertheless it is a substantial downgrade from "making extraordinary things happen in organizations." In addition to being more ambitious, the Kouzes and Posner challenge of achieving ethical and highly productive outcomes is already much more developed, much more central to the current climate of uncertainty when PR practice is faster moving and unpredictable, and continues to be driven by rapid technological innovation, the globalisation of business and the development of the Internet (Arthur Page Society, 2007). Kouzes and Posner's (2012) practices are also much readier for implementation through having distilled research findings from empirical evidence and 
experience gleaned from over a quarter of a century of leader interviews, questionnaires, and other assessment instruments. These are presented in easily comprehensible fashion with tales from the field, and are ready to be turned into immediate action as in their core five, simple-to-grasp leadership practices:

1. Model the Way

2. Inspire a Shared Vision

3. Challenge the Process

4. Enable Others to Act

5. Encourage the Heart (summarized from p. 29)

Berger and Meng (2010) lack such clarity, and sticking close to PR for guidance on PR leadership, they increase the five practices to nine principles, and generate repetition and overlap between their individual principles. Principle one, for example, simply complicates Model the Way by turning it to "Lead by example: . . model the way through two-way communication and exemplary behaviors [Italics in original; bold added by authors] (p. 428). In echoing the Kouzes and Posner text, Berger and Meng (2010) do nothing but add on the now-contested "two-way communication" formula. One big question arises: why would anyone not use the proven five practices, which are strengthened by a raft of supporting tools (e.g., the free and time-tested Leadership Practices Inventory)? Again they stay in the gravitational force field of the Grunigian paradigm as evidenced by the fact that Berger and Meng's (2010) reference list cites half as many (six) PR Excellence readings as general leadership readings (12).

The pull of that paradigm is confirmed in Berger and Meng's (2010) second principle: "Participate effectively and credibly in strategic decision-making arenas in organizations. ... The ultimate public relations leader is a strategic counsellor who's engaged in important decision-making moments in the dominant coalition in the organization (J. E. Grunig, 1992)" (p. 428). The link is explicit and the idea is damaging to expansive leadership ideas in general and to public relations leadership in particular. It restricts both ends of the leadership spectrum. At the top positional end, instead of complaining that PR should be at the top table, the field could be arguing for more PR people to become CEOs and targeting research time on those who have succeeded (both those who head up PR agencies and the heads of non-PR organizations) in attaining their peak positions.

Ironically chapter one of Kouzes and Posner (2012) starts with what they frame as the "inspiring" tale of Barby Siegel, who as "CEO of Zeno Group, an award-winning, multidisciplinary public relations firm .... [ [with] the kind of spirit that fuelled the extraordinary growth and willingness to take risks that PRWeek cited in 2011 when it awarded Zeno two of its top honors" (Kouzes \& Posner, 2012, p. 9). It is salutary to observe that top leadership gurus are willing to come to the PR field to find top leaders, while leading PR leadership researchers go to PR to find top PR leaders rather than benchmark with CEOs everywhere.

\section{External benchmarking (3): Leadership everywhere and for everyone}

As a result, Berger and Meng (2010) set the benchmark too low at the top end, PR leaders should be researching the best of the best CEOs everywhere and using the findings to 
empower PR practitioners to seek wider CEO positions with the qualities that Barby and her team captured in the language "fearless, collaborative, creative, decidedly different, and nimble" (Kouzes \& Posner, 2012, p. 10). None of the short definitions of Berger and Meng's (2010) nine principles feature any of those descriptors. Moreover, as they lower the bar at the top end of leadership, they raise it too high at the bottom by restricting participating to "strategic decision-making arenas" (p. 428). It is accepted wisdom in contemporary leadership literature that, "Leadership Is Everyone's Business" (Kouzes \& Posner, 2012, p. 329). Creating "leaderful organizations" also matters for gender equity. Given that women are the majority in PR education and the profession, every woman needs to be encouraged to see themselves as leaders from the day that they begin study through to the day that they retire, if not longer.

Kouzes and Posner (2012) underline that view repeatedly with supporting citations from outstanding leaders in many different fields as in this one from a leader in the medical field: "Everybody is a leader whether you supervise a group of people or not. . . . Titles don't make you a leader. It's how you behave that makes a difference" (David Kim, cited p. 16). Not surprisingly, given their length and complexity, Berger and Meng's (2010) set of nine principles are much harder to follow. Furthermore, given that their theory covers such a diverse range of qualities - including leading by example, participating in strategic decision making, exemplifying a strong ethical orientation, self-knowledge, serving as an agent of change, possessing complex communication skills, and a strong desire to lead, as well as passion that inspires others - it is hard to clearly define the parameters of excellent leadership in PR.

For too long PR has concentrated too much attention on navel-gazing that aims to find and celebrate our uniqueness as a discipline and our discipline's unique leadership and special leadership needs. Accordingly, we advocate moving the spotlight away from current PR leadership ambitions, practices, and perceptions because they link to low achievement ceilings rather than what we could be as leaders. Instead we direct attention onto how to go about creating more PR CEOs outside the PR sector by building on the leadership literature, and, rather than settling for trusted counsellor roles and a place at the table, for fostering leadership everywhere in PR through building "leaderful" organizations. Even in the more practical guidance of leading PR practitioners, the ambition is low. Lukaszewski's (2008) Why Should the Boss Listen to You? The Seven Disciplines of the Trusted Strategic Advisor adds no leadership-centered theory and suggests that the top position for practitioners is again not the CEO but the trusted counsellor.

At this stage let us rebalance some of our criticism of the Plank Center by acknowledging its contributions. While seeking to redirect more of its energies outwards, we still support the impulse behind its initiatives, the resources it has made available on the website, and its heavy investments in researching and improving PR leadership. It should also be congratulated for setting up summit meetings with influential participants from both education and practice, as well as initiating an admirably open policy for grant-giving. Without the Plank Center, even less PR leadership of note would have appeared and the US dialogue, and the beginnings of international dialogue - including this article - would not be primed to happen. 


\section{External benchmarking (4): Harvard projects and reflections}

Nohria and Khurana's (2010a) Handbook of Leadership Theory and Practice appeared in the same year as Berger and Meng's chapter. It emerged from a colloquium organized as part of the centennial celebrations of Harvard Business School, which the editors saw as "an extraordinary opportunity for the school . . . to take stock of our past and to imagine our future" (Nohria \& Khurana, 2010b, xii). Unfortunately, as their acknowledgements entry admits, "in this crucible of reflection ... we discovered how far leadership research now lagged the espoused mission of most business schools - to educate leaders - and how urgent the need was to spur leadership on the topic" (p. xii). Accordingly, this is an edited volume with "one primary purpose - to stimulate serious scholarly research on leadership" (Nohria \& Khurana, 2010c, p. 3) and after the self-criticism of the acknowledgements it starts off with the hard questions:

when societies around the world are crying out for more and better leadership, when our current leaders (especially in business, but also in government and other spheres of public life) have lost legitimacy, questions are being asked, sometime angrily, of the institutions that school these leaders: What advice can scholars give leaders?" (p. 3).

Nor do Nohria and Khurana (2010b) shrink from self-critical answers: "Our view, as editors of this volume, is that the current state of scholarly research on leadership doesn't allow us to answer these questions with confidence" (p. 3). To redress this state of affairs, their volume encourages "serious research on leadership" (p. 4) while making "no pretense that we already have the answers" (p. 4).

Their modest starting point for leadership, seems like a good starting point for PR leadership. PR still has a low standing in public opinion and considerably fewer CEOs than Harvard Business School. While we don't know the answers either, we think that Nohria and Khurana's (2010) approach is worth following in PR. They are exemplary in the outwardlooking width of their search. They gather leadership researchers from the academy (including from the Cornell School of Industrial and Labor Relations as well as the Harvard Kennedy School of Government) and creative practice (including economists, Pixar animators, and psychologists). These all offer distinctive insights and a rich seam of advances in knowledge that have the potential to offer advances in leadership knowledge and knowing how to lead. Yet none of that knowledge contributes without it being learnable and teachable.

For that we turn to our final benchmark: Snook, Nohria, and Khurana's (2012) The Handbook for Teaching Leadership: Knowing, Doing, and Being. Their book offers a useful framework for transforming leadership challenges by a tripartite division into four sections. The first three are headed Knowing, Doing, Being. Section one, Knowing, "contains various approaches to teaching leadership that emphasize the cognitive domain. The unifying assumption is that knowing about leadership helps prepare future leaders for the effective practice of leading" [italics in original] (Snook, Khurana, \& Nohria, 2012, pp. xv-xvi). Section 2 , "Doing, examines key behavioural aspects of leading" (p. xvi) and section 3, Being, 
"contains essays that focus primarily on the identity of leaders, their character, their values, who they are as human beings" [italics in original] (p. xvi).

If PR leadership interventions were to develop that tripartite structure, They would enable a clear start and a way to divide up the different areas of learning that are involved. Again, there is no need to reinvent the wheel but an urgent reorientation toward already existing wheels that can help turn knowledge into better leadership learning. And the final section reinforces our key message of being self-critical and of looking outwards: "Section IV: Context, expands our horizons beyond traditional university classroom settings to sample a few of the more innovative approaches in the field where unique contextual considerations play a significant role in the design and delivery of leadership education" ( $p$. xvi). The tools for PR practitioners and scholars to know, be, and perform better leadership are close to hand. It is time to reduce our navel-gazing for unique internal PR leadership and start to use what's ready, waiting, and actionable elsewhere.

\section{References}

Aldoory, L. (1998). The language of leadership for female public relations professionals. Journal of Public Relations Research, 10, 73-101.

Aldoory, L., \& Toth, E. (2004). Leadership and gender in public relations: Perceived effectiveness of transformation and transactional leadership styles. Journal of Public Relations Research, 16(2), 157-183.

Arthur W. Page Society (2007). The Authentic Enterprise. Downloaded on 28/01/12 from http://www.awpagesociety.com/images/uploads/2007AuthenticEnterprise.pdf

Authors (forthcoming). Redistributing PR leadership: The sciences of uncertainty for uncertain times.

Berger, B. K., \& Meng, J. (2010). Public relations practitioners and the leadership challenge. In R. L. Heath (Ed.), The SAGE handbook of public relations(pp. 421-434). Thousand Oaks, CA: Sage.

Berger, B. K., \& Reber, B. H. (2006). Gaining influence in public relations: The role of resistance in practice. Mahwah, NJ: Lawrence Erlbaum.

Berger, B. K., Reber, B. H., \& Heyman, W. C. (2007). You can't homogenize success in communication management: PR leaders take diverse paths to top. International Journal of Strategic Communication, 1(1), 53-71.

Bolden, R. (2011). Distributed leadership in organizations: A review of theory and research. International Journal of Management Reviews, 13, 251-269.

Brown, R. E. (2010). Symmetry and its critics: Antecendents, prospects, and implications for symmetry in a postsymmetry era. In R. L. Heath (Ed.), The Sage handbook of public relations(pp. 277-292). Thousand Oaks, CA: Sage Publications.

Budd, J. E. (1993). CEO credibility: The management of reputation. Lakeville, CT: Turtle.

Choi, Y. \& Choi, J. (2008). Dimensions of leadership in public relations: Exploring an organisation wide perspective. Paper presented at the annual meeting of the International Communication Association, Montreal, Canada.

Demetrious, K. (2013). Public relations, activism, and social change: Speaking up. New York, NY: Routledge.

Fairhurst, G. T. (2011). The power of framing: Creating the language of leadership. San Francisco, CA: Jossey-Bass. 
Gilpin, D. R., \& Murphy, P. J. (2008). Crisis management in a complex world. Oxford, UK: Oxford University Press.

Gronn, P. (2002). Distributed leadership as a unit of analysis. Leadership Quarterly, 13, 423451.

Grunig, L., Toth, E., \& Hon, L. (2001). Women in public relations: How gender influences practice. New York: Guilford Press.

Heath, R. L. (Ed.) (2013). Encyclopedia of public relations(2nd. ed.). Thousand Oaks, CA: Sage.

Heath, R. L. (Ed.) (2010). The SAGE handbook of public relations. Thousand Oaks, CA: Sage. Heath, R. L., \& Waymer, D. (2009). Activist public relations and the paradox of the positive: A case study of Frederick Douglass' "Fourth of July Address." In R. L. Heath, E. L. Toth \& D. Waymer (Eds.) (2009). Rhetorical and critical approaches to public relations II(pp. 195-215). New York, NY: Routledge.

Holtzhausen, D. R. (2012). Public relations as activism: Postmodern approaches to theory and practice. New York, NY: Routledge.

House, R. J., Hanges, P. J., Javidan, M., Dorfman, P. W., \& Gupta, V. (2004). Culture, leadership, and organizations: The GLOBE study of sixty-two cultures. Thousand Oaks, CA: Sage.

Javidan, M., Dorfman, P. W., Howell, J. P., \& Hanges, P. J. (2010). Leadership and cultural context: A theoretical and empirical examination based on Project Globe. In N. Nohria \& R. Khurana (Eds.), Handbook of leadership theory and practice: An HBS centennial colloquium on advancing leadership(pp. 335-376). Boston, MA: Harvard Business Press.

Kotter, J. P. (1990). A force for change: How leadership differs from management. New York, NY: The Free Press.

Kouzes, J.M., \& Posner, B.Z. (2012). The leadership challenge: How to make extraordinary things happen in organizations (5th. ed.). San Francisco, CA: Jossey-Bass.

Jin, Y. (2009). Emotional leadership as a key dimension of public relations leadership: A national survey of public relations leaders. Paper presented at the annual conference of the International Communication Association, Chicago.

Kellerman, B., \& Rhode, D. L. (Eds.). (2007). Women and leadership: The state of play and strategies for change. San Francisco, CA: Jossey-Bass.

Li, C. (2010). Open leadership: How social technology can transform the way you lead. San Francisco, CA: Jossey-Bass.

McKie, D., \& Munshi, D. (2007). Reconfiguring public relations: Ecology, equity, and enterprise. London: Routledge.

Megill, A. (2011). Epilogue: On the current and future state of historical writing. In A. Schneider \& D. Woolf (Eds.), The Oxford history of historical writing: Volume 5: Historical writing since 1945(pp. 678-688). Oxford, UK: Oxford University Press.

Moloney, K. (2006). Rethinking public relations: PR propaganda and democracy. Abingdon, UK: Routledge.

Nohria, N., \& Khurana, R. (Eds.). (2010a). Handbook of leadership theory and practice: An HBS centennial colloquium on advancing leadership. Boston, MA: Harvard Business Press. Nohria, N., \& Khurana, R. (2010b). Acknowledgements. In N. Nohria \& R. Khurana (Eds.), Handbook of leadership theory and practice: An HBS centennial colloquium on advancing leadership(pp. xii-xiv). Boston, MA: Harvard Business Press. 
Nohria, N., \& Khurana, R. (2010c). Advancing leadership theory and practice. In N. Nohria \& R. Khurana (Eds.), Handbook of leadership theory and practice: An HBS centennial colloquium on advancing leadership(pp. 3-25). Boston, MA: Harvard Business Press. Northouse, P. G. (2007). Leadership: Theory and practice(4th. ed.). Thousand Oaks, CA: Sage. Northouse, P. G. (2010). Leadership: Theory and practice(5th. ed.). Thousand Oaks, CA: Sage. Northouse, P. G. (2013). Leadership: Theory and practice(6th. ed.). Thousand Oaks, CA: Sage. Raelin, J. A. (2003). Creating leaderful organizations: How to bring out leadership in everyone. San Francisco, CA: Berrett-Koehler.

Snook, S., Khurana, R., \& Nohria, N. (2012). Teaching leadership: Advancing the field. In S. Snook, N. Nohria, \& R. Khurana (Eds.). The handbook for teaching leadership: Knowing, doing, and being(xi-xxix). Thousand Oaks, CA: Sage.

Snook, S., Nohria, N., \& Khurana, R. (Eds.). (2012). The handbook for teaching leadership: knowing, doing, and being. Thousand Oaks, CA: Sage.

Uhl-Bien, M. (2006). Relational leadership theory: Exploring the social processes of leadership and organizing. The Leadership Quarterly, 17(6), 654-676.

Werder, K. P., \& Holtzhausen, D. R. (2009). An analysis of the influence of public relations department leadership style on public relations strategy use and effectiveness. Journal of Public Relations Research, 21(4), 404-427.

Yukl, G. W. (1989). Leadership in organisations. Englewood Cliff, NJ: Prentice Hall. Yukl, G. A. (1999). An evaluation of conceptual weaknesses in transformational and charismatic leadership theories. Leadership Quarterly, 10(2), 285-305. 